\title{
O Ante-projeto de Código das Obrigações
}

\author{
Lino de Morais Leme
}

\author{
PARTE GERAL
}

I A orientação geral

1. Publicado o Ante-projeto de Código das Obrigações (Parte Geral), cumpre aos juristas debatê-lo, para que êle seja uma obra digna de nossa cultura, e tão perfeita quanto possivel.

Se é um dever dos juristas, maior ainda êle é para os que professam o Direito Civil. Eis porque sáio a campo, para dizer o que penso sobre o trabalho. E faço-o porque "Amicus' Plato, sed magis amica veritas".

2. Elaborado por uma Comissão, composta de três eminentes mestres, o Ante-projeto é um trabalho que honra os seus autores, que já gosam de grande renome. Tenho, porém, idéias, restrições e observações, a apresentar, em uma colaboração de bôa vontade, que, estou certo, será recebida com a largueza de espírito, que é apanágio da ilustre Comissão.

3. Bem andou a douta Comissão em unificar o Direito Privado em matéria de Obrigações, reservando para - Código Comercial apenas os institutos peculiares ao comércio. Essa Parte Especial tanto podia constituir um título do Código Civil, como formar a matéria do Código Comercial.

A favor da dualidade e da unidade do Direito Privado se alinham grandes nomes, no estrangeiro e em nossa Pátria. Aquí se manifestaram, pela unificação, TerxeIra 
de Freitas, Carlos de Carvalho, Coelho Rodrigues, Brasílio Machado, Lacerda de Almeica, InglÊs de Sousa, Valadão; e, pela dualidade, principalmente Clovis Bevilaqua.

$\mathrm{O}$ fato de a Constituição se referir ao direito civil e ao comercial não impede a unificação, pois, realizada ela, ficaria, no campo do direito comercial, a sua matéria especial. Assim, tambem, não é pelo fato de existirem o direito viéreo e o direito operário (melhor se diria direito do trabalho!), referidos especialmente na Constituição, que se irão destacar princípios gerais do Código Comercial, para um, ou do Código Civil, para outro.

Não vou enumerar os argumentos dos favoraveis à dualidade, para combatê-los, ou os dos favoraveis à unidade, para apoiá-la. Basta-me salientar que as normas gerais são as mesmas, no Direito Civil e no Direito Comercial, e que os mesmos institutos em regra são governados por idênticos princípios.

Por isso, bem fazem a jurisprudência inglesa e a americana, que não conhecem regras particulares aos comerciantes, nem uma teoria de atos de comércio.

4. Na apresentação do Ante-projeto, percebe-se que o pensamento é de, ao Código das Obrigações, seguir-se o da Propriedade e o da Família, "ligado a esta o Direito das Sucessões". D'aí se infere que a classificação da matéria obedece ao mesmo critério do Código Civil. Dele diverge, sob esse aspeto, apenas quanto à Parte Geral, que a Comissão pensa em restringir, ou mesmo suprimir, pois ela "resulta de um processo de técnica, que dificulta o ensino e a apreensão imediata do sentido das normas jurídicas".

Mesmo que a Parte Geral projetasse raros reflexos sobre as outras partes do Código Civil, que não o Direito das Obrigações, não seria motivo para suprimí-la. Para demonstrá-lo, basta recordar que os códigos francês e italiano, por exemplo, não têm Parte Geral; não obstante, muitos autores francêses e italianos fazem preceder a exposição da Parte Especial de uma Parte Geral, à semelhança dos Códigos alemão e brasileiro. E o Projeto de Código Civil ar- 
gentino, que levou dez anos para ser elaborado - constituida a Comissão em 1936, foi o Projeto apresentado em 1936 e ainda não foi convertido em lei — preferiu o modelo alemão e brasileiro.

Mas, não me parece que tenham razão os que pretendam que as normas referentes aos fatos jurídicos só interessem ao Direito das Obrigações. No usofruto não podem encontrar-se a condição e o termo? Nos direitos reais de garantia, o termo? Na servidão, no usofruto, etc., os vícios da vontade? No reconhecimento de filhos, na adoção, o erro, o dolo, a coação? No art. 1.590 não há referência a vícios da vontade? A partilha não pode ser anulada por erro (art. 1.805)?

5. Não há como contestar deva um Código ter uma Parte Geral, ou Título Preliminar. Se não a tiver, onde colocar as regras sobre a obrigatoriedade, a retroatividade, a revogação das leis? Onde os princípios referentes às pessôas jurídicas, uma vez que as outras partes seriam o Código de Família e o Código da Propriedade?

Entre os códigos que mais restringiram esse Título preliminar, figuram o da França, o do Chile, o da Suissa e o do Ururguái; nem esses, porém, dispensaram-na. Portanto, parece exagerado o pensamento constante da Exposição de motivos, com o qual foi apresentado o Ante-projeto, acenando até para a supressão da Parte Geral.

Há alguns anos foi publicado o projeto de reforma do Código Civil argentino, da autoria de Juan ANtónıo BaBILONI, revisto por uma comissão de que, além do seu autor, faziam parte Salvat, Lafallle, Rébora, Rivarola, Martinez Paz, Gervasoni, Pera e Repetto, nomes de grande projeção nas letras jurídicas, sendo um membro do Supremo Tribunal, dois membros de Tribunais de Apelação, quatro professores de Direito Civil, o autor, membro da Academia Nacional de Ciências Jurídicas, e um representante do Instituto dos Advogados da Capital Federal. Pois bem: os membros dessa Comissão, apartando-se do Código argentino, preferi- 
ram o modelo alemão e o brasileiro, porque o acharam "mais lógico"; e na Apresentação do Projeto ao Poder Executivo, após outras considerações, concluiram: "Los elementos inherentes a toda relación jurídica, figuran así reunidos y clasificados, con un alcance y un vigor más eficaces".

Quanto aos artigos referentes aos atos ilícitos, há tempos sustentámos que deveriam passar para a Parte Especial.

6. A divisão do Código em duas partes, uma geral e outra especial, foi preconizada por ThiBaut, MüHLEMBruch, Mackeldey e outros, recebendo, em Portugal, o apoio de Coelho da Rocha, e, no Brasil, o de Teixeira de Freitas, Coelho Rodrigues e Clovis Bevilaqua. E as razões são as mesmas constantes da Apresentação do Projeto de Código argentino.

Sem dúvida que as várias partes dos códigos "hão de concatenar-se necessariamente em um sistema geral"; mas há certos princípios fundamentais que constituem o alicerce sobre que assenta a Parte Especial do Código, ou que são como o eter, que cerca e penetra todas as cousas; o conhecimento dessa Parte Geral é como uma introdução para as normas que a seguir são estabelecidas sistematicamente.

7. Não estamos de acôrdo em que esse processo dificulte o ensino. Ao contrário, é um meio excelente para se gravarem no espírito princípios básicos, que a cada passo são objeto de referência. Pois se é um processo mais lógico!

8. Não se pode contestar que os princípios da Parte Geral sejam necessários, afóra um ou outro, que contém matéria doutrinária.

Nem se diga que a parte referente aos Fatos jurídicos, do Código Civil, projeta raros reflexos sobre a Parte Especial, pois é incontestavel que eles se verificam em todas as divisões da mesma.

A necessidade de uma Parte Geral ainda se evidencia no ensino: o Prof. Raví, por exemplo, da Universidade de Pádua, inicia o seu curso com uma introdução, em que en- 
contram logar, além de outras, noções sobre os fatos jurídicos e seus elementos.

Tratemos de melhorar, conservando. A inovação pretendida, sobre não trazer vantagem nem representar uma necessidade, parece demonstrar o nosso espírito de versatilidade, adorando hoje o que hontem condenámos. E nada mais é do que abandonar o modelo alemão para aceitar o critério suisso, e justamente quando uma notavel Comissão argentina entendeu de se nortear, nessa parte, pelo modelo alemão e brasileiro. Não seja o fato de alguns civilistas alemães se manifestarem contrários à Parte Geral, que vamos despresar a opinião de outros notaveis civilistas, a tradição de nosso direito e as conveniências reconhecidas.

9. Parece-me que preliminarmente se devera estabelecer o plano do futuro Código, resolvendo-se definitivamente, além da questão referente ao Título Preliminar ou Parte Geral, a referente à ordem de colocação da Parte Especial, tanto mais que se não diz ter ficado deliberado que cada uma das divisões da Parte Especial viesse a constituir um Código.

Acredito que essa possibilidade será afastada. A não ser que haja uma parte do Direito Privado, sucetivel de ser unificada, não se justifica essa denominação para cada uma das partes do Código Civil.

O Código suiço separou o Código das Obrigações, para unificar o Direito Privado, em relação a elas. Não é pelo fato de haver Códligo de Pesca, Código de Caçá, Código de Ar, Código de Minas, Código das Aguas, Código Florestal, Código dos Interventores, Código do Ministério Público, Código de Menores, Código Sanitário, Código de Contabilidiade, Código de Polícia Sanitária Animal Código de Trânsito, etc. - sem falar no Código do Escoteiro, no Código de Bom Tom e outros -, que vamos matar o Código Civil, para surgirem - Código das Obrigações, o Código da Família, o Código da Propriedade. Aliás, o último não seria verdadeiramente um Código da Propriedade, porque em alguns desses códigos há dispositivos a ela referentes... E no Código da Faimí- 
lia seria mister encaixar o Código de Menores, a Lei de proteção d̀ framília...

10. A justificação do Ante-projeto ameaça-nos com um Código das Sociedade e um Código dos Transportes. Se essa é a idéia, irá ficar amputado desnecessariamente o Código Civil. Compreende-se que haja uma lei especial, regulando as sociedades por ações, mas custa a admitir que a sociedade e o transporte, elementos importantes para a atividade do indivíduo, não se encontrem disciplinados em um Código das Obrigações, parte de um Código Civil.

Estão na moda o "reajustamento" e o "código". Será que tambem deste reajustamento do Código Civil irão surgir outros códigos?

11. Para concluir estas primeiras observações:

a) O futuro Código deve ter uma Parte Geral ou um Título Especial, e esse assunto devêra ser preliminarmente fixado;

b) A Parte Especial deve ser ordenada como no Código alemão, e essa matéria deveria também já ter sido resolvida.

\section{II - A distribuição da matéria.}

1. A matéria está dividida em cinco títulos - Constituição, Classificação, Transmissão, Extinção e Inexecução dias Obrigações.

2. Na enumeraão das fontes ou modo de constituição das obrigações, o Ante-projeto seguiu evidentemente o Código Japonês. Mas, o capítulo primeiro, Da declaração da vontade, dá a impressão de haver sido acrescentada uma fonte obrigacional; e o artigo primeiro parece confirmar essa hipótese.

Não acredito, porém, que realmente isso se tenha verificado. Sem dúvida, a vontade unilateral pode ser fonte de obrigações, mas sòmente nos casos expressos. 
Isso posto, vê-se que o capítulo primeiro devera ser um capítulo preliminar.

3. Por isso que o contrato é a fonte comum das obrigações, devera ele vir em segundo logar, relegada a Promessa de recompensa para depois da Gestão de negócios.

4. O nosso Código Civil incorre num defeito de técnica, reunindo, sob o título Dos efeitos das obrigações, os efeitos e os casos de extinção das mesmas. O Código português ainda diz - Dos efeitos e cumprimento das obrigações. Os códigos francês, taliano, chileno, argentino, suiço, entre outros, distinguem os efeitos e a extinção das obrigações.

O Ante-projeto procura corrigir a falha do código, mas denomina Da inexecução das obrigações o título referente aos efeitos. Este vocábulo é de sentido mais geral, e preferivel, porque há normas relativas ao mesmo que se não enquadram no título adotado e que poderiam constituir secções de um capítulo subordinado ao título que lembro. Para esse título poderia ser transportado o capítulo referente à Mora, que mal se adapta ao título $D a$ extinção dias obrigações. A móra, por certo, não é um caso de extinção... E o direito de retenção poderia constituir uma secão do capítulo referente à inexecução das obrigações.

Eu preferiria que o capítulo sobre Efeitos das obrigações abrangesse a Inexecução, a Mora, a Estipulação em favor de terceiros, a Garantia das obrigações e a Revogação dos atos fraudulentos (Grarantias e Revogação se não houver um capítulo - Das garantias pessoais das obrigações).

Havendo esse título deveria o mesmo compreender as Garantias Gerais (Ação revocatória, Ação subrrogatória, Separação de patrimônios), as Garantilas especiais (Privilégios, Direito de retenção) e as Garantias convencionais (Arras, Clausula penal, Fiança, Caução).

5. Foi acertada a idéia de tirar a gestão de negócios dos contratos em espécie. Alguns códigos a incluem no grupo dos quasi-contratos, orientação que vem do D. R. O Cod. alemão a coloca entre as obrigações diversas (como o Pro- 
jeto argentino); o Cod. suiço entre os contratos. O Código se aproximou deste. A aproximação com o mandato explicaria a colocação após ele, entre os contratos, mas não se justificaria, por não se configurarem nela os elementos do contrato.

6. Bem andou o Ante-projeto em introduzir um capítulo sobre o enriquecimento indevido, a exemplo do código alemão, do suiço, do japonês e do Proj. argentino. $O$ princípio existia em vários artigos, mesmo porque se trata de uma verdade jurídica universal. Mas o melhor era dar-lhe corpo no Código.

7. O Ante-projeto enumera, entre as fontes de obrigações, a Reparação Civil.

Qual a razão que levou o Ante-projeto a adotar essa expressão, não empregando a de Atos ilícitos:

a) o entender que o abuso de direito não é ato ilícito?

b) o querer abranger a reparação dos danos originados do contrato?

De qualquer forma que seja, a expressão é infeliz, pois a reparação é efeito e não causa.

E reparação civil... A pena criminal passaria a ser reparação criminal... A ser aceitavel o vocábulo reparação, o título devera ser antes reparação do dano.

Para o Código austríaco, há tres fontes de obrigações: o contrato, a lei e o dano causado, abrangendo, nesta expressão, tres das fontes das obrigações não convencionais do Código francês: o quasi-contrato, o delito e o quasi-delito. Dano causado seria expressão aceitavel, em vez de atos ilícitos, ou fatos ilícitos. Estas, porém são as expressões consagradas (fato, diz o Código suiço; atos dizem o Código alemão (Unerlaubte handlungen), o japonês, o argentino (O Código holandês só considera duas as fontes: o contrato e a lei).

8. Mas, porque não incluir o abuso de dineito na categoria dos atos ilícitos, como o fez o Código alemão? Ou o ato é lícito, ou ilícito.

Quer-se dizer que também os atos lícitos obrigam a indenizar, e que o sistema do Ante-Projeto é este: para os 
atos ilícitos, exigir a culpa, e para o abuso de direito aceitar a teoria do risco? Mas o Ante-Projeto conceitua o abuso de direito como o "procedimento contrário e prejudicial aos bons costumes e às normas de convívio social". Pois não está aí a iliceidade? Demais, a responsabilidade objetiva, resultante da prática de atos lícitos, deve resultar de disposições excecionais. Erigí-la em regra geral seria faltar ao sistema, além da dificuldade em se classificar os atos causadores de dano, em uma categoria, ou em outra.

9. Teria sido o objetivo de abranger, nas regras sobre a reparação civil, também a dos danos resultantes do contrato? Não o suponho, porquanto o Título $I$ distribuiu as fontes das obrigações em capítulos, e uma há referente aos Contratos; neste é que caberiam essas normas, se o Anteprojeto não as deixasse para o título $-D a$ inexecução das obrigações.

Mas o Ante-projeto se trái, quando, no art. 155, dispõe: "Não constituem atos ilícitos.." A contrário sensu, fóra desses casos o ato culposo, causando prejuizo a outrem, é um ato ilícito.

10. Não há, no Ante-projeto, referência à extinção das obrigações, pela confusão. Julgou-se talvez, dispensavel qualquer referência especial, à vista do dispositivo do art. 332. Mas, esse dispositivo está mal colocado na parte referente à inexecução das obrigações. O seu logar próprio é no título - Da extinção das ıbrigaçães. E as hipóteses dos artigos 1.051 e 1.052 do Código Civil?

11. Não compreendo como a prescrição esteja no capítulo da Inexecução das obrigaçães, e não no da Extinção. Pareceu-me que se teve receio de algurem argumentar que o Código a considera um caso de extinção de direito e não de extinção da ação...

Essa questão se prende a outra - aplicar-se o instituto da prescrição aos direitos não patrimoniais, assunto que exige mais largo exame, que será feito em outro capítulo. 
12. Eu preferia que o Ante-projeto tivesse a distribuição e denominações seguintes:

Tít. I - Da constituição das obrigações.

Cap. preliminar - Da declaração de vontade, com as mesmas secções do Ante-projeto, mas acrescentando-se 0 encargo, à secção $3 .^{\mathrm{a}}$;

Cap. I - Dos contratos.

Cap. II - Da gestão de negócios.

Cap. III - Da promessa de recompensa.

Cap. IV - Do enriquecimento ilícito.

Cap. V - Dos fatos ilícitos.

Tít. II - Das modalidades das obrigações (as mesmas secções do Ante-projeto, sob o título - Da classificação das obrigações).

Tít. III - Dos efeitos das obrigações (Inexecução, Mora e estipulações em favor de terceiros).

Tít. IV - Das garantias das obrigações.

1. Gerais (Ação revocatória, Ação subrrogatória, Separação dos patrimônios).

2. Especiais (Privilégios e Direitos de retenção).

3. Convencionais (Arras, Cláusula penal, Fiança, Caução).

Tít. V - Da transmissão das obrigações ( como no Ante-projeto).

Tít. VI - Da extinção das obrigações (os capítulos do Ante-projeto, mais um sobre Confusão e outro sobre Prescrição).

III - Os capítulos I e II do Título I: Da declaração de vontade e Da promessa de recompensa

1. O art. $10^{\circ}$ dispõe: "Contrai obrigação quem declare a vontade de satisfazer a favor de outrem uma prestação".

Uma lei deve evitar, o mais possivel, as definições. 0 ensinamento do fr. 202, de Javolenus, de reg. juris D. (50-17), é velho e sempre novo. 
Dessa regra do art. $10^{\circ}$ se infere o conceito de obrigação: é a declaração de vontade de satisfazer uma prestação a favor de outrem. Uma pessôa declara que vai escrever um discurso para outrem. Pelo Ante-projeto, haverá aí uma obrigação?

Os escritores trazem o conceito de obrigação, mas não uniformemente. Os códigos em geral não a definem. Porque, pergunta o professor Ravà, definir um conceito do qual o próprio homem comum tem a intuição?

Melhor é definir o ato jurídico, como o fazem o nosso Código e o Projeto argentino.

2. Sem um dispositivo semelhante ao do art. 1.097, do Código Civil, o Ante-projeto trata do "silencio" - e que é estranhavel. Nem se diga que o mesmo era dispensavel: códigos há que não admitem o consentimento tácito, outros que só o admitem nos casos expressos, e, outros, sòmente no caso de a parte não poder falar ou escrever. Em regra, admitem-no; mas as exceções mostram a necessidade de se manter o dispositivo citado.

3. Quánto ao silêncio, há a considerar os elementos acessórios e os principais.Em relação àqueles, há a lembrar os prazos de caducidade, a aplicação supletiva da lei, os elementos naturais do ato jurídico. A inscrição em um curso ou concurso importa aceitação das condições estabelecidas, como nos contratos de adesão. A dificuldade está em relação ao consentimento, elemento essencial dos contratos. $E^{\prime}$ bem de ver que os casos de eficácia jurídica do silêncio são mais restritos no direito civil do que no comercial, em que os usos e costumes têm um campo bem maior. E fóra os casos originados dos costumes, é mister que a lei estabeleça a presunção legal de consentimento.

O Código de Lusiana prevê expressamente o silêncio, nos arts. 1.805 e 1.810. Diz o primeiro: "A proposta ou aceitação de um contrato é tácita, quando manifestada por atos ou mesmo pelo silêncio ou a inação, nos casos em que as circunstâncias autorizam a interpretá-los assim, ou nos que dão logar à presunção legal de consentimento". E o 
Projeto argentino estabelece no art. 137: "El silencio será juzgado como asentimiento a un acto o a una pregunta, cuando exista deber legal da explicarse, o bien a causa de la relación entre el silencio actual y la conducta anterior del agente. La manifestación de voluntad sólo puede ser presumida en casos previstos por ley expresa".

O Ante-projeto diz: "Art. 2..$^{\circ} \mathrm{O}$ silêncio importa anuência, quando, segundo o costume ou as circunstâncias do caso, como tal deva ser interpretado". Não faz referência aos casos que acarretam a presunção legal de consentimento. Por isso, de acordo com o que escrevi em meu opúsculo, Eficácia jurídica do silêncio, proponho assim se redija: "Art. 2. A declaração de vontade pode ser tácita, quando a lei não exigir que seja expressa. Parágrafo único. O silêncio valerá consentimento nos casos expressos e quando, segundo os costumes ou as circunstâncias, como tal deva ser interpretado".

4. 0 art. $30^{\circ}$ é uma redundância: a regra já está no art. 71 , n. IV, onde pode ficar a exceção; e como já há para o n. II, podiam ambas as exceções ficar em parágrafo a esse artigo: "Prarágrafo único. Nos casos dos ns. II e IV, valerá a declaração, se a lei cominar sanção diferente".

5. Proponho que o art. $4 .^{\circ}$ assim se redija: "A escritura pública é essencial para constituição ou transmissão de direitos reais sobre imoveis de valor superior a um conto de réis, salvo as exceções expressas".

6. 0 art. $5 .^{\circ}$ reproduz, com outras palavras, mais ou menos, a regra do art. 386 da Consolidação de Teixeira de Freitas, sanando uma omissão do Cod. Civil.

Proponho, porém, outra redação:

“Art. 5. A escritura pública será lavrada em livro de notas, por oficial competente, e deverá ter a data, a indicação do logar, a declaração de leitura e a subscrição pelo oficial, pelas partes e por duas testemunhas, no mínimo.

“§ 1. Poderá terceiro, ou qualquer das testemunhas, assinar a rôgo da parte que não o saiba ou não o possa 
fazer. Nesse caso, poderá constar do livro a impressão digital de quem devia subscrever $o$ ato.

"§ 2.․ As partes ou as testemunhas, que não forem conhecidas do oficial, deverão provar a sua identidade e deixar, no livro de notas, as impressões digitais da mão direita".

A prova da identidade deve ficar a critério do serventuário; e é aconselhavel a cautela alvitrada, que facilita a identificação, quando mistér.

7. Ao art. 6. ${ }^{\circ}$, proponho a seguinte alteração:

"Art. 6. ${ }^{\circ}$ Além da escritura pública, consideram-se instrumentos públicos:

I - os traslados e certidões:

a) dos atos judiciais;

b) dos atos constantes de cartórios, arquivos e estabelecimentos ou repartições públicas;

II - as notas dos corretores oficiais, que tenham livros regularmente escriturados, quando pelos mesmos subscritas;

III - os conhecimentos e cartas de fretamento e os contratos de câmbio marítimo, que tiverem os requisitos legais;

IV - os atos dessa natureza passados em paiz estrangeiro, de acôrdo com suas leis, legalizados pelo consul brasileiro e traduzidos".

A enumeração do artigo é incompleta (cf. Cod. Comercial, arts. 52, 569 e 587). Em relação ao n. IV, cabe notar que é um corolário do disposto no art. 12 da Introd. ao Cod. Civil.

8. Quanto ao art. $7 .^{\circ}$, sugiro a seguinte redação, e que ao mesmo se incorpore o $\S 2 .^{\circ}$ do art. $80^{\circ}$ :

"O documento assinado provará a obrigação, quando a lei não estabelecer fórma especial.

Parágrafo único.Presumem-se os documentos ou instrumento particulares terem a data do reconhecimento das assinaturas neles lançadas, ou da entrada dos mesmos em repartição pública ou juntada a autos judiciais".

9. Quanto ao art. 8., sugiro a seguinte redação:

"Valerão contra terceiros: 
a) os documentos ou instrumentos particulares, desde a data em que constarem dos registros públicos, ou derem entrada em repartições públicas, ou forem juntos a autos judiciais;

b) os livros comerciais, quando se admitir a prova por esse meio".

10. Proponho a seguinte redação para o art. $9 .^{\circ}$ :

“Os atos jurídicos, a que se não impuzer fórma especial, poderão provar-se mediante:

I - documentos;

II - confissão;

III — testemunhas;

IV - presunções;

$\mathrm{V}$ - exames e vistorias;

VI - arbitramento".

11. O art. 11 suprimiu a frase "salvo os casos expressos", do art. 141 do Cod. Civil, e que deve ser restabelecida, pois casos há em que se dispensa o escrito, como no depósito necessário, no comodato.

Outrossim, convém eliminar, do $\S 22^{\circ}$, a expressão do comércio, não só porque o fato se pode dar fóra do comércio, como tambem porque a restrição pode ocasionar polêmicas.

12. Vejo, no art. 12, dois inconvenientes:

— um, a inclusão do "dependente das partes" entre os que não podem ser admitidos como testemunhas. O gráu de dependência pode tornar a testemunha suspeita, mas não deve acarretar o impedimento da prova;

- outro, o parágrafo único, em que se anula o artigo. Não se deve ir além do que concede o art. 143 do Código Civil, podendo apenas dar-se outra redação, para se incluir o "casamento". Ficaria assim o parágrafo:

“O parentesco não acarretará impedimento para ser testemunha, quando se tratar de ato que deva constar de assento do Registro Civil". 
13. Parece-me desnecessário o adjunto adverbial "quando exigida esta formalidade" e conveniente incluir-se "a matrícula de comerciantes". Assim ficaria o art. 13:

"No registo de comércio serão feitos o arquivamento e inscrição de documentos ou instrumentos de carater mercantil, salvo as exceções expressas, bem como a matrícula de comerciante".

14. $O$ art. 17 tem certamente sua fonte no art. $\mathbf{1 1 6}$ do Cod. alemão, e destina-se a substituir parte do art. 102 do Código Civil.

Penso que seria conveniente acrescentar-se: "A reserva não prejudicará a terceiros, de bôa fé".

15. Emenda ao art. 19: Substituir "enquanto" "por" "até quando".

16. $O$ art. 31 dispõe: "E' anulavel a declaração pela qual um pessôa, sob premência de necessidade, ou por inexperiência, se obriga a prestação manifestamente desproporcionada ao proveito resultante da prestação oposta". E' o preceito do Cod. suisso, art. 31, já incorporado ao Projeto argentino, art. 156.

A Consolidação das Leis Penais tem um dispositivo semelhante: o do art. 338, n. 7.': "Abusar, em próprio ou em alheio proveito, das paixões ou inexperiência do menor, interdito, ou incapaz, e fazê-lo subscrever ato que importe efeito jurídico, em dano dele ou de outrem, não obstante a nulidade do ato emanado da incapacidade pessoal". Não haveria necessidade de o Código das Obrigações reproduzir a proibição, a não ser para lhe dar um alcance maior.

Assim se restabelece o instituto da lesão, que o D. R. limitava ao caso de ser maior do que metade do preço, orientação seguida pelo Código francês, e que o Código brasileiro não manteve, julgando suficientes os preceitos sobre erro e dolo.

O Código suiço, porém, estabelece uma prescrição curta para a ação, nesse caso (1 ano). Pelo Projeto argentino, o contrato é nulo. 
Embora o Ante-projeto o declare anulavel, e ainda com os temperamentos dos parágrafos $10^{\circ}$ e $2 .^{\circ}$, contudo a prescrição não deve ter prazo maior do que o estabelecido pelo Código suiço, não só por motivo da estabilidade necessária nos negócios, como tambem para evitar que a chicana encontre aí campo para demandas temerárias.

17. $\mathrm{O}$ art. 37 permite o contrato consigo mesmo, a exemplo do art. 181 do Cod. al. Este, porém, diz que o representante não o pode fazer "se autorização não lhe é dada"; o Ante-projeto diz - "não pode... salvo se a lei ou o representado o permitirem"

Tem havido na doutrina e na jurisprudência estrangeira, tendência em se admitirem os contratos consigo mesmo. No D. R., houve caso excepcionalissimos em que se permitiu a uma pessôa representar mais do que uma, o que levou Cícero a escrever - unus homo multas personas sustinere potest; mas não se permitia isso na compra e venda.

Em nosso direito, a tendência é para não admitir os contratos consigo mesmo, como resulta dos arts. $1.133,428$ n. I, e por arg. do art. 387.

Que se admita a regra do Cod. alemão, porquanto se o representado autorizou o ato, pode-se por ficção admitir que é ele quem no mesmo intervem. Mas, acrescentar que a lei tambem pode autorizar, não me parece curial; pois não é em virtude de autorização de lei que o representado pode autorizar o ato?

18. Considerando-se instrumento público a procuração, por instrumento particular, com a letra e firma reconhecidas, desaparece a necessidade do artigo.

19. Proponho que o art. 40 tenha a redação do art. $1.289 \S 10^{\circ}$ do Código Civil, substituindo-se "circunscrição territorial" por "distrito", e que se lhe acrescentem, como parágrafos, os de n. II e IV desse artigo.

20. Proponho se redija o art. 43: 
"no caso de exceder os poderes que tiver, o representante ficará responsavel para com as pessôas com quem tratar em nome do representado".

Porque exigir que ele tenha feito a prova desses poderes? Basta o disposto no art. 47, para completar o artigo.

21. Emenda ao art. 47; se for conservada a redação do artigo: dizer "ato excedente" em vez de "ato excessivo".

22. Emenda ao art. 48;

ao n. III:

Diga-se "pelo implemento de condição resolutiva, de termo final, bem assim pela conclusão do negócio";

ao n. IV :

Diga-se "extinguindo-se o ato em que ela se funda, ou cessando a situação que a determinou".

A conservar-se a mesma redação, deve dizer-se "quando se extinguir".

23. O art. 53 resa: "A obrigação pode ser contraida sob condição ou a termo. E' dispositivo inutil. Se o Anteprojeto, a seguir, diz que a condição é "o evento futuro e incerto, de cuja verificação a vontade das partes faz depender o nascimento ou a extinção das obrigações", está visto que "a obrigação pode ser contraida sob condição". Por outro lado: do art. 1.278 decorre que as obrigações podem ser contraidas a termo.

A enumeração tem o inconveniente de omitir o encargo, que tem suas peculiaridades, mas que não deixa de ser uma modalidade das declarações de vontade. $O$ fato de a condição e o termo serem modalidades que resultam da declaração da pessôa que obriga, constituindo um onus ou uma imposição, não é motivo para ele ser omitido. Pode ele ser incluido entre as condições, com as quais às vezes é confundido, mas tem a sua fisionomia própria.

O Ante-projeto, no entanto, não o considera especialmente, como fez o Cod. Civ., no art. 128. 
24. Penso que 0 art. $55,1 .^{\mathrm{a}}$ parte, devia redigir-se assim :

"São lícitas as condições que não forem contrárias à lei, à moral ou aos bons costumes"

Deve haver apenas duas categorias - a das condições lícitas e a das ilícitas. Estas devem compreender as espécies - contrárias à lei, à moral e aos bons costumes. art. 56.

Com essa redação, torna-se dispensavel a $2 .{ }^{a}$ parte do

25. Com referência às condições impossiveis :

- O Código as considera inexistentes (art. 116), portanto, válidas as obrigações a elas subordinadas;

- O Ante-projeto declara que as suspensivas invalidam as obrigações a elas subordinadas.

O Ante-projeto distingue as condições impossiveis em suspensivas e resolutivas, para admitir a validade apenas destas, afastando-se do Cod. francês (art. 1.173) e italiano (art. 1.161), que apenas consideram válida a obrigação de não fazer cousa impossivel.

Considero louvavel a orientação do Ante-projeto, mas proponho que o artigo se redija:

"A condição impossivel, quando resolutiva, considera-se inexistente; quando suspensiva, anula a obrigação a ela subordinada".

26. De acôrdo com o sistema do Ante-projeto, proponho que, no art. 57, se substitua "ato" por "declaração de vontade", mas acho preferivel deixar, do artigo 60, apenas o parágrafo, redigindo-se o art. 57 , portanto, da seguinte fórma:

"Verificando-se a condição, a obrigação a ela subordinada nasce, quando suspensiva, e extingue-se, quando resoIutiva".

$0 \S$ único do art .60 passa a artigo.

27. OCódigo Civil, em matéria de interpretação das declarações de vontade, tem apenas os dispositivos dos artigos 85 e 1.090, ao contrário de vários códigos, como o francês, o italiano, o espanhol, o chileno, o uruguáio, que repro- 
duziram as regras extraídas do D. R., por Pothier. Os códigos de Portugal e do México se contentaram com dois artigos. O Código alemão se limita a um artigo, o 157, que manda interpretar os contratos pelas regras de bôa fé e pelos costumes. Tambem o Código suiço se limita a um artigo - o 18.

A matéria é mais doutrinária, mas não há inconveniente em se conservarem os artigos do Ante-projeto. Proponho, porém, ao art. 67, o acréscimo de "dispõe a lei ou", antes de "é usual", e que se suprima a expressão "em tais casos", que é desnecessária. A primeira alteração torna claro que o uso não prevalecerá sobre a disposição supletiva da lei.

28. O artigo $71, \mathrm{n}$. II, resolve o caso de proibição legais, sem sanção expressa, a respeito das quais silenciava o Código Civil.

29. Em matéria de Promessa de recompensa, o Anteprojeto inclui a obrigação de o promitente indenizar, quando retire a promessa, as despesas feitas de bôa fé, em virtude da mesma, como no Código suiço - no que fez bem.

A redação "vincula-se à obrigação" me parece inconveniente: a obrigação é um vínculo; portanto, equivaleria a "víncula-se a um vínculo". Melhor é a redação do Código - "contrai a obrigação".

IV - Os capítulos III a VI, do Título I (Contratos, Gestão de de negócios, Enriquecimento indevido e Reparação civil)

1. O Ante-projeto trata, no art. 89, dos contratos por meio de correspondência epistolar ou telegráfica. Mas não são essas as únicas fórmas de contratos entre ausentes. Por isso, o Código edita as normas do art. 1.081, e depois, no 1.086, fixa o momento em que se tornam perfeitos os contratos por meio de correspondência.

Parece-me preferivel conservar o 1.081 e modificar o 1.086. E, nessa modificação, atender-se a que há contra- 
tos que se considerem perfeitos quando não forem recusados dentro de um prazo razoavel.

2. O Projeto argentino considera o caso de proposta de várias pessôas ou a várias pessôas, o de remessa de listas de preços, tarifas, etc., e o de proposta alternativa. Penso que se devera regular essas hipóteses.

3. 0 art. 93 diz: "A promessa unilateral de contrato vale, ao arbítrio de quem a recebe, dentro no prazo que lhe foi fixado".

Promessa unilateral de contrato é proposta de contrato. Convém, no entanto, modificar a redação, para evitar dificuldades semelhantes às que encontraram os autores italianos, diante do art. 36 do seu Código: "Nei contratti unilaterali le promesse sono obbligatorie appena giungono a notizia della parte cui sono fatte".

4. O art. 94 exige, para o contrato preliminar, a mesma fórma que para o contrato definitivo, para obrigar a este, estabelecendo, em caso contrário, o ressarcimento do prejuizo.

Como conciliar essa orientação como os decretos n. 58 de 10.12.37 e 3.079, de 15.9.38? Dir-se-á que são leis especiais; mas seria conveniente declarar — "salvo os casos especiais".

5. $\mathrm{O}$ art. 96 estabelece: "A impossibilidade relativa da prestação não invalida o ato, salvo o caso do art. 322, ou cessando antes de realizada a condição".

Não é justo que fique prejudicada a parte que ignorava a impossibilidade, tanto que o Proj. argentino lhe reconhece o direito à indenização pelos prejuizos.

0 artigo ressalva o caso do art. 322. Portanto, nesse caso $o$ ato fica sem valor. Mas este dispositivo permite ao juiz modificar o cumprimento da obrigação, prorrogando-lhe o termo ou reduzindo-lhe a importância, o que não é invalidar o ato.

6. O art. 97, tratando da estipulação em favor de terceiro, dá a este o direito de exigir o cumprimento da obri- 
gação. O Código diz - se o estipulante o não inovar. Essa condicional deve ser mantida.

7. Em relação ao mesmo assunto, ocorre observar que nem o Código, nem o Ante-projeto, cogitam da renúncia do terceiro, como o faz o Projeto argentino, no art. 849.

8. O Ante-projeto diz que as arras constituem princípio de pagamento (art. 105). E se não forem em dinheiro?

9. Quando as arras não forem princípio de pagamento, devem ser restituidas após a execução do contrato ou o seu desfazimento (art. 105, § único). Uma das fórmas do "desfaizmento" é a rescisão judicial. Ora: verificada a impossibilidade da prestação, ou a rescisão do contrato, por culpa do que deu as arras, ele as perde (art. 106), sem prejuizo da indenização que ainda seja devida. Quer dizer que o Ante-projeto seguiu o Código alemão, art. 338, que manda imputar as arras na indenização, ao contrário do Código suiço, que permite, ao que recebeu, guardar as arras, sem imputá-las no seu crédito. Mas seria conveniente, para evitar uma aparente contradição, redigir mais claramente, dizendo-se, como o Cod. alemão, que, se o pedido de perdas e danos couber ao que recebeu as arras, estas nelas devem ser imputadas, e, não sendo possivel, devem ser restituidas, depois de paga a indenização.

10. Quanto aos vícios redibitórios, faço as seguintes sugestões:

a) dizer "com perdas e danos", e não "com a indenização", como está no § único do art. 109;

b) dizer "em hasta pública ou em leilão", e não "em leilão público", como diz o art. 111;

c) aumentar para o dobro o prazo para a extinção do direito, em relação às cousas moveis;

d) regular a hipótese de vícios redibitórios, no caso de vendas conjuntas, como no Projeto argentino (1390);

e) estabelecer a indivisibilidade da ação, permitindo a responsabilidade dos herdeiros do alienante, pela quota que lhes corresponda, como no Projeto argentino (1.393). 
11. Não me parece justificavel o art. 118, senão na parte em que permite seja a ação de evicção intentada diretamente contra qualquer dos alienantes anteriores. Nesse caso, eu proporia a seguinte redação: "O proprietário evicto se considera subrrogado nos direitos dos adquirentes an. teriores, pelo que poderá intentar a ação diretamente contra os alienantes que devam responder pela evicção".

12. O art. 127 está em colisão com o 116. E, no caso de coisa alheia ou litigiosa, não se deve exigir que o alienante tenha assumido o risco da evicção. Assim deve ficar o artigo: "Não poderá o adquirente demandar pela evicção, se não foi privado da coisa pelos meios judiciais, salvo o disposto no art. 116, bem assim se sabia que a coisa era alheia ou litigiosa".

13. O Ante-projeto não cogita da evicção entre permutantes, a-pesar-de o Código Comercial ter, a respeito, os artigos 222 e 223. A lacuna, porém, poderá ser sanada na Parte Especial.

14. O Código, no art. 1.331, estabelece a responsabilidade do gestor para com o gerido e para com as pessôas com quem tratar. O Ante-projeto julgou dispensavel essa parte final, e eu penso que ela deveria ser conservada.

15. O Código exige a prova de erro, para repetiçáo do pagamento indevido. O Ante-projeto, seguindo o Projeto argentino (art. 85), concede a repetição, haja erro, ou não. 0 projeto argentino, porém, não permite a repetição, quando cientemente foi paga uma obrigação inexistente (art. 858, 1. ${ }^{\circ}$, exceção que o Ante-projeto devera consagrar.

16. O Ante-projeto permite repetição ao que paga antes de vencido o prazo (art. 144), e não o permite no que paga uma obrigação sujeita a condição suspensiva, antes de verificada a condição?

17. Seria conveniente que o Ante-projeto incorporasse um artigo em que se permitisse o não cumprimento de obrigaçăo sem causa, mesmo que estivesse prescrita a ação para libertar-se da dívida, a exemplo do Projeto argentino, art. 863. 
18. Bem andou o Ante-projeto em procurar conciliar a doutrina da culpa com o do risco, estabelecendo a culpa objetiva, que corresponde ao ato anormal, de Saleilles.

19. O Ante-projeto diz, no art. 154: persistindo a res ponsabilidade subsidiária, naturalmente para evitar o emprego de subsistindo tão próximo desubsidiária. Eu preferiria dizer - sem prejuizo da responsabilidade subsidiária.

20. 0 art. 155, $\S 3 .^{\circ}$, dizendo: "Se o terceiro não atende à citação, considera-se revel", reproduz inutilmente uma regra de direito judiciário.

21. A preocupação da clareza levou a dizer-se, no art. $154 \S 3 .^{\circ}$ : "chamar aquele a juizo". Mas, dizendo-se "chamá-lo a juizo", nenhuma dúvida aparece.

22. Em matéria de atos ilícitos, o Ante-projeto se afastou das censuras feitas ao nosso Código, por não estabelecer a presunção de culpa juris tantum, no caso de responsabilidade indireta. Em meu trabalho sobre Responsabilidade civil fóna do contrato tratei do assunto, com algum desenvolvimento. Entendo que, nos casos do art. 160, ns. II e III, do Ante-projeto, devera declarar-se a solidariedade dos responsaveis diretos e indiretos, para tornar claro que é livre ao prejudicado escolher a pessôa contra quem agir, como fez o Cod. Civil, no art. $1.510 \S$ único. Não me parece esteja essa solidariedade abrangida pela norma do art. 169.

São lamentaveis os artigos que estabelecem gráus de culpa: o 172, estabelecendo que "o juiz fixará a indenização de acordo com a gravidade da culpa, consideradas as circunstâncias do caso"; o art. 321, na parte em que se refere à culpa grave. Será o restabelecimento da velha questão sobre os gráus da culpa, como acentuou muito bem o eminente dr. Júlio de Faria.

Naturalmente o Ante-projeto se inspirou no art. 44 do Código Suiço das obrigações, que diz: "Lorsque le préjudice n'a été causé ni intentionellement ni par l'effet d'une grave négligence ou imprudence, et que sa réparation exposerait le débiteur à la gêne, le juge peut équitablement ré- 
duire les dommages - intérêts". Mas não atendeu à situação especial prevista pelo legislador suiço.

23. Penso que em vez do moderadamente, do art. 181, seria preferivel o equitativa, que o Código suiço emprega no art. 47.

V - Da classificação, transmissão, extensão e inexecução das obrigações

1. O Ante-projeto é demasiado rigoroso, quando exige, para uma obrigação de fazer poder ser cumprida por terceiro, que conste essa faculdade do título da obrigação. Pode ser indiferente o cumprimento da obrigação pela parte, ou por terceiro, como se se trata de arar um campo. Por isso encontramos na legislação comparada a orientação de se não admitir essa possibilidade:

- quando o credor tem interesse na execução pessoal (Cód. suiço, art. 68),

- se o credor for prejudicado (Cod. português, art. 1.437),

- quando se teve em conta a qualidade e as circunstâncias da pessoa do devedor (Cod. espanhol, art. 1.161),

- quando não for indiferente a qualidade de executor (Cod. do Perú),

- quando o devedor tinha sido escolhido por sua arte, indústria ou qualidades pessoais (Projeto argêntino, art. 628).

2. O Ante-projeto não considera, no art. 199, a impossibilidade de desfazer o ato, como o fazem vários códigos, entre os quais o argêntino, o francês e o Projeto argêntino (art. 631).

3. Por que estabelecer que a obrigação alternativa é ineficaz, se o objeto de uma delas for ilícito? E' converter a obrigação em facultativa, e em principal a obrigação ilícita. A regra é que a inexigibilidade ou a impossibilidade de uma não afeta a outra. Qual a razão para a iliceidade de uma tornar a outra ilícita? 
4. O Código Civil não considerau especialmente as obrigações conjuntas e as facultativas, por ser desnecessário. Em relação a estas, é evidente que elas se equiparam às obrigações alternativas em que a escolha compete ao devedor.

5. O Código Civil foi cauteloso, não consignando a obrigação de pagar, no caso de pluralidade de credores, ao que exigir a dívida judicialmente. A consignação atende ao interesse do credor que assim reclama e ao dos demais que não deram caução de que ratificariam o pagamento.

6. O art. 214 evidentemente encerra uma omissão, somente referindo-se ao direito à dívida toda. Na solidariedade passiva se trata de obrigaçấo pela dívida toda.

7. O Código Civil estabelece, no art. 945, que a entrega do título firma a presunção de pagamento, que pode ser ilidida, no prazo estabelecido no parágrafo primeiro. 0 art. 270 não se refere a um prazo especial, que parece conveniente, para a segurança dos negócios.

8. Considerando a hipótese de serem designados, para o pagamento, dois ou mais logares, o Código Civil estabelece que compete ao credor escolher (art. 950, parágrafo único). O Ante-projeto fala da designação dos logares, alternativamente, para determinar que a escolha compete ao devedor, como é a regra, nas obrigações alternativas. E quando os logares forem indicados conjuntamente?

9. O art. 276 fala em "coisa certa e determinada". Haverá coisa certa indeterminada?

10. $O$ art. 278 estabelece uma regra geral. Embora possa haver regra especial, como a do art. 1.264 do Código Civil, não seria demais que se ressalvassem os casos expressos.

11. Em matéria de imputação de pagamento, o Anteprojeto segue a orientação do Código Civil, e do Projeto argentino (art. 719), permitindo ao devedor fazer a imputação, quando as dívidas forem líquidas e vencidas. E se as dfvidas não estiverem vencidas, ou se houver algumas nessas 
condições, não se deve permitir ao devedor que nelas impute o pagamento, salvo se parcial, não o admitindo a lei, não sendo o termo a favor do credor, ou não existindo condição não verificada? A regra romana era melhor: est in arbitrio solventis dicere, quod potius debitum voluerit solutum (fr. 1, D. 43-1). Se o devedor não faz a imputação, competirá ao credor fazê-la subsidiariamente, nos termos fixados na lei.

12. $\mathrm{O}$ art. 303 do Ante-projeto consigna regra contrária à do art. 998 do Código Civil. E' conhecida a controversia existente entre os sabinianos e os proculeianos, de que resultaram os textos antinômicos de Marciano e Ulpiano. Carvalho de Mendonça, Obrigações, v. I, a elas se refere, em o n. 339, e se coloca ao lado de Marciano.

O Projeto argentino (art. 730) segue o Código alemão, aplicando, no caso, as regras sobre a evicção.

E' verdade que no Código Civil havia, quanto à matéria, uma certa contradição, quando ele equipara a dação à compra e venda, e determina, no caso de evicção, a revivescência da obrigação. Mas em nossa opinião devera a alteração limitar-se a suprimir ou modificar o art. 896 , já que a colocação do instituto mostra que a dação é uma forma de pagamento. Pelo menos a evicção resultante de ação hipotecária deve ter essa solução.

13. Oart. 321 estabelece: "Não vale a cláusula pela qual se estipule a exoneração da responsabilidade por dolo ou culpa grave". Embora a cláusula somente possa existir no contrato, pode pretender-se que a mesma se aplique tambem à responsabilidade extra-contratual. O Cod. suiço das obrigações contem um dispositivo semelhante, no art. 100.

Há alguns escritores, como Demogue (Resp. civ., v. V n. ${ }^{\circ}$ 1.199), Saleilles (Obligations, n..$\left.^{\circ} 16\right)$, partidários da equiparação da responsabilidade civil contratual e extra-contratual, sob esse aspeto. Estou, porém, com Fromageot, De la faute, p. 65 e segs., Hudelot et Metman, Obligations, n. 422, Sourdat, Traité de resp., v. II, p. 679 e segs., Chironi, Colpa extra-contr., v. II, p. 588 e segs. 
14. $\mathrm{O}$ art. 322 pretende introduzir, em nosso direito, a cláusula da imprevisão, que o direito canônico adotara para o contrato "qui habet tractum succesivum et dependentiam de futuro rebus sic stantibus", e que vários autores apoiam para os contratos a longo termo, em virtude, da sucessiva mudança no estado de fato em que foram concluidos.

Os argumentos que alguns escritores apresentaram, para justificá-la, como a intenção comum das partes, a equidade, são inaceitáveis. A bôa fé a justificaria, não fosse a dificuldade de aplicação da cláusula. E, para protegerse a bôa fé, ir-se-ia abrir a porta para a má fé.

O desiquilibrio das prestações não é motivo para anular-se o contrato, exceto no caso do art. 31 do Ante-projeto, e não o deve ser para a revisão do contrato.

Nem se argumente que seria injusto a não adoção do principio da imprevisão. Para a maioria dos casos, bastará a regra relativa ao caso fortuito ou de força maior. Para os outros, proverão as leis especiais. $\mathrm{O}$ fato de as nossas leis não terem uma norma que permitisse a revisão dos contratos, não impediu que em vários tempos leis excepcionais provessem às necessidades ocorrentes.

A revisão dos contratos é apenas admissivel em matéria de serviços públicos, ou em casos especiais, como no contrato de empreitada.

Levantam a bandeira da bôa fé, como se o direito nela se não fundasse, e argumentam com esquecimento do princípio do caso fortuito, os partidários da regra perigosa, reproduzida do art. 269 do Cód. polonês.

15. Pretende o art. 328 que a taxa dos juros moratórios seja a bancária, no logar de pagamento, para os empréstimos ordinários. Mas essa taxa é variavel, e, portanto, não poder servir de padrão para esses juros. O preferivel é seguir a orientação do Código Civil. Quando for conveniente a alteração, uma lei a fará.

16. 0 art. 334 dispõe: "Ficando perempto o direito do credor, este somente pode invocá-lo por via de exceção". 
Parece que "perempto o direito" equivale a "prescrita a ação".

E' a revivescência da imprescritibilidade das exceções, que se deixou influenciar pela orientação do Código francês e dos que o seguem, empregando a expressão "prescrição aquisitiva" e não o vocábulo "usocapião".

Compreende-se a imprevisibilidade da exceção em favor do devedor. Fora essa hipótese, apenas na fórma estabelecida pelo Código italiano, art. 1.302.

17. O Ante-projeto parte do pressuposto que a prescrição é inaplicavel ao Direito de Família, ao Direito das Cousas, ao das Sucessões. Será que ele parte deste pensamento - onde a lei fala em prescrição de direito, tratarse-á de decadência, e onde em prescrição de ação, será propriamente prescrição? Não o creio, pois não seria científico, como a tentada enumeração casuística dos casos de decadência.

Espinola, Dir. Civ., v. 1. ${ }^{\circ}$, p. 603, ensina:: "o prazo da extintiva abrange todo o domínio do direito civil, aplica-se a toda a classe de relações jurídicas". Idêntico é o ensinamento de Carpenter e de outras notabilidades.

Em matéria de Direito de Familia, o erro vem de se não haver entendido convenientemente a regra - "O estado e a capacidade não prescrevem". Para se ver o verdadeiro sentido, basta o art. 194 do Cod. alemão!" O direito de exigir de outrem uma ação ou abstenção (reclamação) é submetido à prescrição. A reclamação que deriva de uma relação de familia não é sujeita à prescrição, quando tem por fim a restabelecimento, para o futuro, de um ato de acôrdo com essas relações" - (Cf. Carpenter, pags. 200 e 201).

o Cod. suiço, ao estabelecer, no art. 127, a regra sobre prescrição das ações, se reporta a dispositivos do Código Civil, alguns referentes às ações de estado.

E no Direito das Cousas não há as ações dominicais, servitudinárias, usufrutuárias, hipotecárias, etc.? No di- 
reito das Sucessões, as ações de petição de herança ou legado, de sonegados, de colação, de nulidade de partilha, etc.?

Qual o conceito de decadência? Dalloz considerava-a a perda de um direito, por falta de exercício, ou do cumprimento de uma condição ou de uma formalidade, num tempo dado. Pugliese - um direito em via de formação que, não efetivado em certo tempo, morre antes de haver desenvolvido a sua eficácia. Não seria aceitavel o conceito de Dalloz, suprimindo-se o exercício? Decadência ha em casos como o de reclamação contra lançamento de impostos, de prazos nas clausulas especiais à compra e venda, no comisso, etc. D'aí extender-lhe o domínio e dizer - a prescrição é instituto do Direito das Obrigações, a decadência, das demais divisões do Código Civil, é forte e é inadmissivel, por falta de base.

18. No art. 31, o Ante-projeto inclui, entre os casos previstos no art. 338, n. 7.', da Consolidação das Leis Penais, o de premência de necessidade, o que equivale a restabelecr o instituto da lesão enorme, pois, quem não puder invocar outro fundamento, tem esse. 0 art. 172 manda regular a indenização de acordo com a gravidade da culpa. E o art. 322 admite a revisão dos contratos por imprevisão.

Por esses tres artigos se enfeixa, nas mãos juizes, uma soma tão grande de arbitrio, que quasi equivale a dizer-lhes: A lei está nas vossas decisões.

Felizmente, temos no Brasil, e especialmente em S. Paulo, que melhor conhecemos, uma magistratura animada pela luz eterna da justiça.

Das considerações feitas, e de outras, resultam as seguintes :

\section{Sugestões}

1. Não devem ser feitos códigos separados, e muito menos um Código das Sociedades e outro Código dos Transportes, O Código Civil deve conservar a sua unidade. 
2. Conservar a Parte Geral do Código Civil, menos os artigos referentes aos autos ilícitos.

Se não for aceita a sugestão, denominar Capítulo preliminar o Da declaração dia vontade.

A tradição de nosso direito, a conveniência de a Parte Geral preceder a Especial, o reflexo que a mesma tem sobre todo o direito, aconselham a preferência do modelo alemão, recentemente seguido pelo Projeto argentino, ao modelo suiço.

3. O Capítulo Dos contratos deve estar em 2. lugar.

4. Deve adotar-se o título Dos ef eitos da obrigação, em substituição ao Da inexecução das obrigações. Esse título deve conter disposições gerais sobre os efeitos das obrigações entre as partes, seus sucessores e terceiros. As secções $D a$ estipulação em favor de terceinos e Da mora devem ser para aí transportados.

Seria conveniente incluir-se, nesse título, um capítulo - Do direitito de retenção.

5. O título - Da reparação civil - deve ser substituido por Dos atos ilícitos. A' reparação é efeito e não causa.

6. Suprimir o artigo $1 .^{\circ}$, ou substituí-lo pelo conceito de fato e de ato jurídico, ou alterar-lhe a redação.

7. Antes do artigo sobre o silêncio, deve haver um sobre o consentimento tácito. E a parte sobre o silêncio deve fazer referências aos casos expressos em lei, em que ele vale consentimento.

8. Parece-me redundante $o$ art. $3 .^{\circ}$, à vista do $71, \mathrm{n}$. IV, onde pode ser acrescentada a exceção. art. $40^{\circ}$

9. E' supérflua a frase "à validade da declaração", do

10. E aconselhavel nova redação para o art. 5. ${ }^{\circ}$ "A escritura pública será lavrada em livro de notas, por oficial competente, e deverá ter a data, a indicação do logar, a declaração de leitura e a subscrição pelo oficial, pelas partes e por duas testemunhas, no mínimo. 
$\S 10^{\circ} \quad$ Poderá terceiro, ou qualquer das testemunhas, assinar a rogo da parte que não o saiba ou não o posso fazer. Nesse caso, poderá constar do livro a impressão digital de quem devia subscrever o ato.

$\S 2 .^{\circ}$ As partes ou as testemunhas, que não forem conhecidas do oficial, deverão provar a sua identidade e deixar, no livro de notas, as impressões digitais da mão direita".

11. 0 art. $60^{\circ}$ é omisso: não se refere às hipóteses dos artigos 52, 569 e 587, do Cdigo Comercial. Sugiro outra redação :

“Art. 6. Além da escritura pública, consideram-se instrumentos públicos:

I - os traslados e certidões:

a) dos atos judiciais;

b) dos atos constantes de cartórios, arquivos e estabelecimentos ou repartições públicas;

II - as notas dos corretores oficiais, que tenham livros regularmente escriturados, quando pelos mesmos subscritas;

III - os conhecimentos e cartas de fretamento e os contratos de câmbio marítimo, que tiverem os requisitos legais;

IV - os atos dessa natureza passados em paiz estrangeiro, de acôrdo com suas leis, legalizados pelo consul brasileiro e traduzidos".

12. Sugiro nova redação para os artigos $7 .^{\circ}$ e $8 .^{\circ}$.

“Art. 7. $\mathrm{O}$ documento assinado provará a obrigação, quando a lei não estabelecer forma especial.

Parágrafo único. Presumem-se os documentos ou instrumentos particulares terem a data do reconhecimento das assinaturas neles lançadas, ou da entrada dos mesmos em repartições públicas, ou juntada a autos judiciais".

"Art. 8. Valerão contra terceiros:

a) os documentos ou instrumentos particulares, desde a data em que constarem dos registros públicos, ou derem entrada em repartições públicas, ou forem juntos a autos judiciais;

b) os livros comerciais, quando se admitir a prova por esse meio". 
13. Proponho se altere o art. $90^{\circ}$ e se acrescentem a confissão, os exames e vistorias e o utrbitramento. Ficaria assim:

"Art. 9. Os atos jurídicos, a que se não impuzer forma especial, poderão provar-se mediante:

$$
\begin{aligned}
& \text { I - documentos; } \\
& \text { II - confissão; } \\
& \text { III - testemunhas; } \\
& \text { IV - presunção; } \\
& \text { V - exames e vistorias; } \\
& \text { VI - arbitramento". }
\end{aligned}
$$

14. 0 art. 11, $\S 1 .^{\circ}$, deve ressalvar os casos como o de depósito necessário.

15. São inconvenientes o $\mathrm{n}$. IV, em que se acrescenta o dependentes das partes, e o $\S$ único, em que se anula o artigo (art. 12).

16. E' desnecessário o adjunto adverbial "quando exigida esta formalidade". Outrossim, parece-me conveniente a inclusão da matrícula do comerciante (art. 13).

17. Julgo se dever acrescentar, no art. 17, que a reserva não prejudicará terceiros de bôa fé.

18. $O$ art. 31 deve consignar uma prescrição curta, como a do Cod. suiço, art. 21.

19. Não é mister a referência à lei, no art. 37 .

20. E' preferivel substituir a redação do art. 40 pela do art. $1.289 \& 10^{\circ}$, do Cod. Civil.

21. Não será melhor substituir o adjetivo excessivo, por excedente, nos arts. 43 e 47 ?

22. 0 art. 53 é inutil. E não há motivo para afastar-se o encargo.

23. Está mal redigido o art. 81.

24. 0 art. 67 deve presumir, primeiramente, o que dispõe a lei.

25. 0 art. 89 trata dos contratos por meio de correspondência epistolar ou telegráfica. Mas o contrato pode ser feito tambem por outra forma. E' melhor dizer os casos em 
que a proposta deixa de ser obrigatória, e, noutro artigo, fixar o momento da perfeição do contrato e permitir a retratação da proposta ou da aceitação, nos termos adotados.

26. $\mathrm{O}$ art. 93 fala em promessa uniliateral de contrato. Porque o adjetivo unilateral? Será que pode haver promessa billateral, que não seja contrato?

E porque "ao arbítrio de quem a recebe"? Não bastaria dizer: "A proposta de contrato é obrigatória dentro no prazo que lhe foi fixado"?

27. O art. 94 não ressalva o consignado nos decretos ns. 58 e 3.079. Deverá acrescentar-se: "e nos casos expressos".

28. 0 art. 96 não está em concordância com o 322, pelo qual se não invalida $o$ ato $e$ sim se lhe corrigem as condições.

29. Quanto ao art. 97: E se o estipulante inovar?

30. Em relação ao art. 99: E se o terceiro renunciar?

31. $\mathrm{O}$ art. $105 \mathrm{diz}$ que as arras constituem princípio de pagamento. E se não forem em dinheiro?

32. O art. 105, § un., diz que, não sendo princípio de pagamento, as arras devem ser restituidas, após a execução ou o "desfazimento" do contrato. Uma das formas do "desfazimento" é a rescisão judicial. Ora: verificada a impossibilidade da prestação, ou a rescisão do contrato, por culpa do que deu as arras, ele as perde (art. 106). Como as poderá restituir?

33. O art. 109 e outros falam em indenização, sem esclarecer se é a dos danos emergentes, ou se abrange tambem a dos lucros cessantes, ou se é a do equivalente. $\mathrm{E}^{\prime}$ melhor a técnica do Código Civil. Aliás, o Ante-projeto fala em perdas e danos, no art. 213.

314. O prazo de prescrição para os vícios redibitórios, em relação às cousas moveis, embora igual ao do Código Civil, é muito curto.

35. O art. 114 fala apenas em leilão público. Devera dizer: em hasta ou leilão públicos.

36. Em matérias de vícios redibitórios, seria util considerar a hipótese de vendas conjuntas. 
37. E' preferivel a fórmula do Código Civil, para caraterizar a obrigação pela evicção (art. 115).

38. Não é justo que, chegando-se a alguem contra o qual se não possa fazer valer a responsabilidade pela evicção, ainda haja o direito contra os seus antecessores (art. 118).

39. O periodo: "No caso de rescisão", etc., é inutil, pois o que ele consigna decorre da rescisão (art. 123).

40. A expressão "na forma do Código de Processo Civil" (art. 126), é desnecessária.

41. O art. 127 não está em harmonia com o 116.

42. O Ante-projeto não trata da evicção entre permutantes, nem do caso de bens divididos.

43. Porque suprimiu o art. 129, do art. 1.331 do Cod. Civil, a declaração da responsabilidade do gestor perante o gerido e terceiros?

44. Seria conveniente acrescentar um artigo estabelecendo que, nos atos para os quais não se exige capacidade, pode o gestor não a ter, e que, sendo incapaz o gerido, depende a gestão de ser ratificada na forma da lei.

45. Quanto ao art. 143: E no caso de ser paga cientemente uma obrigação inexistente (Cf. proj. arg., art. 858) ?

46. $\mathrm{O}$ art. 144 não considera o caso do pagamento antecipado de uma obrigação sujeita a condição suspensiva.

47. O capítulo Do enriquecimento indevido devia considerar o caso de pagamento de obrigação sem causa.

48. Em vez de persistindo, dizer: "sem prejuizo da" (art. 154).

49. E' esdrúxulo o período: "Se o terceiro não atende à citação, considera-se revel” (art. $155 \S 3 .^{\circ}$ ).

50. "Chamar quele a juizo". Porque não - "chamá-lo"?

51. Convem seja expressamente estabelecida a solidariedade entre os responsaveis diretos e indiretos, nos casos do art. 160 , ns. II e III.

52. $\mathrm{O}$ art. 172 é inconveniente. 
53. O art. 878, do Cod. Civil, que foi eliminado, consagra um dos princípios fundamentais da obrigação de dar.

54. O Cod. Civil, no art. 868, § único, diz que os frutos percebidos são do devedor, cabendo ao credor os pendentes. Não são idênticas as fórmulas. A do Ante-projeto permite ao devedor a chicana de colher os frutos, alegando depois que a sua obrigação é a de entregar os frutos pendentes no momento da entrega.

55. No artigo 147, o Ante-projeto se reporta, quanto aos frutos, accessões, benfeitorias e deteriorações, ao disposto quanto à restituição da posse. Ao tratar, porém, da obrigação de restituir (art. 190), nada diz sobre os frutos, a-pesar-de haver, no Cod. Civil, o preceito do art. 873, § único.

56. O art. 192 substituiu o termo técnico "escolha" por "indicação".

57. Pode não resultar do título, e sim das circunstâncias, ou do interesse do credor, que o devedor cumpra pessoalmente a obrigação (art. 194).

58. Porque o art. 198 exige que o cerceamento da liberdade seja abusivo?

59. O art. 199 não considera o caso de ser impossivel desfazer 0 ato.

60. O art. 204 contém uma inovação inaceitavel, quando considera ineficaz a obrigação alternativa, se o objeto de uma delas for ilicito.

61. O art. 205 devêra dispôr justamente o contrário, em relação à obrigação facultativa.

62. Há falta de correlação verbal, no art. 209. Aliás, observa-se que a forma elegante do futuro, seguida pelo Código Civil, é em regra substituida pela do presente.

63. Era preferivel conservar o art. 892, como está, não permitindo o pagamento a quem exigir a dívida judicialmente, e sim determinar que o devedor se exonera exibindo a importância, mais as custas até esse momento (art. 210).

64. Para que o acréscimo da expressão "não beneficiados pelo pagamento", feito no art. 893 do Código, a que corresponde o 211 ? 
65. Em vez de "em dinheiro a quota extinta", dizer: "o valor da quota extinta" (art. 212).

66. A redação do art. 214 é defeituosa. Acrescentar, depois de "direito": "ou obrigação".

67. Porque o adjetivo "expressa", no art. 216?

E porque: "E mediante contrato"?

68. O art. 219 não cogita da remissão, como o art. 903 do Cod. Civil.

69. Em vez de dizer-se pagamento direto $e$ indireto (art. 219), é preferivel especificar - pagamento, novação, compensação, transaçc̃̃o. 0 art. 900 do Cod. não se refere $\dot{a}$ transiação, que o art. 1.031 considera.

70. E' preferivel substituir a fórmula $-O s$ juros $d a$ móra recaem em todos (art. 229). Melhor é a do art. 909 do Cod.

71. O parágrafo único do art. 231 fala em "partè renunciada". A renúncía de dívidas é denominada tecnicamente remissão. Não é melhor dizer - "parte correspondente aos exonerados da solidariedade"?

72. Em vez de "garantes" (art. 243), é preferivel o nosso termo técnico "fiadores". Aquele vocábulo sómente é empregado nos meios rurais.

73. E' melhor a redação do Código - "para desobrigar o devedor" (art. 989) - à do Ante-projeto — "em relação ao devedor".

74. O Ante-projeto emprega o vocábulo "subrrogante" (art. 254) em vez de "originário", como no Cod. (art. 990). A substituição não pode prevalecer, pois há casos de subrrogação não convencionais, e nos quais, portanto, não há subrrogante.

E' de notar ainda que a expressão "ou seu cessionário", que o Cod. não tem, dará logar a dúvidas, pois o subrrogado pode tambem ser cessionário.

75. 0 art. 260 reproduz a primeira parte do art. 937 do Código. Parece-me que se deve acrescentar — "Salvo se ela não dispensar a devolução do título". 
76. Em vez de dizer-se: "É válido o pagamento feito de bôa fé ao que, embora não seja credor, guarde todas as aparências dessa qualidade" (art. 261), não é mais elegante - " $E$ ' válido o pagamento feito de bôa fé ao credor putativo" (aliás, redação do Cod.)?

77. Em D. R., a expressão in rem versio designava não sòmente a entrega da cousa ou do dinheiro, mas tambem o seu emprego util. Daí Giorgi, Obblig. v. 6, p. 29, empregar a frase: "Viersão util". Será porém, aconselhavel a expressão, que a nossa linguagem exige esclarecida (util-a quem)?

78. A redação do último trecho do art. 263 é ambígua". ...poderá constrange-lo a pagar de novo, salvo regresso contra o devedor que recebeu". "Salvo" quer dizer "exceto"? o Cod. diz - "ficando-lhe, entretanto, salvo o regresso contra o credor".

79. Emenda ao art. 269: Diga-se “da principal” e não "do principal".

80. $\odot$ art. 270 devêra consagrar a exceção do $\S 1 .^{\circ}$ do art. 945 do Cod.

81. Em relação ao $\S 10^{\circ}$ do art. 273: E se os logares forem designados conjuntamente?

82. Substituir "exercitam" por "exercem", no art. 273 $\S 20^{\circ}$.

83. O art. 276 fala em "coisa certa e determinada"; haverá coisa certa indeterminada?

84. $O$ art. 276 não considera o caso de prestações relativas a imovel, como o 951 do Código.

85. O art. 278 devêra ressalvar os casos expressos em lei, como os do art. 1.264 do Código.

86. Não é mister a frase "e aceito", do art. 280.

87. O art. 273 devêra esclarecer se é o domicílio do devedor ao tempo do pagamento ou ao tempo do contrato.

88. O Ante-projeto não considera o caso de agravamento da obrigação pela mudança do domicílio do credor. 
89. O art. $288 \mathrm{diz}$ : "quando o credor, sem justa causa, recusa receber o pagamento ou dar quitação regular", e no n. II se refere a "fato involuntário do credor". $E$ quando o fato for voluntário: o pagamento, por ex., é no domicílio do devedor, e o credor não aparece. D’aí a necessidade de um artigo geral, estabelecendo a possibilidade de consignação, pela móra do credor.

90. O Ante-projeto (art. 298), como o Código (art. 991), permite a imputação do pagamento, quando as dívidas forem líquidas e vencidas. Parece que o melhor é dar ao devedor a faculdade de fazer a imputação, sem referência especial às dívidas líquidas e vencidas; e, depois, estabelecer regras para a imputação, não havendo declaração do devedor.

91. 0 art. 303 do Ante-projeto consagra regra contrária à do art. 998 do Código - o que não me parece razoavel. $O$ credor de primeira hipoteca recebe em dação o imovel hipotecado. Um credor, com segunda hipoteca, faz a excussão de seu crédito. Não é justo que se restabeleça a obrigação e até a garantia?

92. O vocábulo "novação" está mal colocado no art. 306.

93. E' melhor integrar o parágrafo único do art. 311 do artigo, dizendo-se: "A compensação se opera mediante declaração do devedor ao credor, e, salvo etc.".

94. $\mathrm{O}$ art. 321 não distingue entre responsabilidade contratual e extra-contratual.

95. O art. 322 é inconveniente. Não se exige a equivalência real das prestações, no momento do contrato, salvo o caso do art. 31 ; não se deve estabelecer essa exigência quando o contrato vai ser cumprido, sob o fundamento de acontecimentos excepcionais e de prejuizo exorbitante, pois seria, pensando-se proteger $a$ bôa fé, abrir a porta para a má fé. Quanto aos casos excepcionais, proverão as leis nessas ocasiões.

A querer introduzir-se, em nosso Código, uma regra semelhante 'à do Código polonês, limitar-lhe a aplicação aos 
acontecimentos excecionais e imprevisiveis (não "imprevistos", como está no Ante-projeto), fixar o limite mínimo do prejuizo, para a revisão, e conceder, ao credor, a faculdade de optar pela rescisão do contrato.

E quando, em virtude desses acontecimentos, uma parte auferir lucro excessivo?

96. O art. 326 dispõe: "A parte lesada pelo inadimplemento pode promover a rescisão do contrato, com perdas e danos". Não seria util ressalvar o disposto no artigo anterior, que estabelece a simples resolução do contrato, havendo fato inimputavel?

97. 0 art. 328 estabelece um regime de incertezas, pois as taxas bancárias variam no mesmo logar. O melhor é seguir a orientação do art. 1.062 do Código.

98. Julgo melhor, em vez da regra do art. 329, do Ante-projeto, uma semelhante ao art. 947, § 2.०, do Código.

99. Os artigos 348 e 349 empregam o neologismo inutil "descumprimento".

100. Porque o art. 353 do Ante-projeto acrescenta "de qualquer natureza" ao art. 927, 1. ${ }^{\mathrm{a}}$ parte, do Cod.?

101. Estará certa a redação do art. 369 , § 1. - "interrupção operada contra um dos credores solidários"?

102. 0 art. $371, \S 3 .^{\circ}, \mathrm{n}$. II, deve ressalvar o caso do $\S 1 .^{\circ}$, n. X. Esta, por sua vez, devera consignar - "salvo os casos expressos" (ex. alugueres, pensões, juros, dividendos, etc.).

Não seria possivel encerrar estas sugestões, escritas com a preocupação de evitar dissertações doutrinárias, que lhe alterariam o objetivo, sem manifestar o entusiasmo e a admiração pelo trabalho da colenda Comissão, integrada por Philadelpho Azevedo, Hahnemann Guimarães e Orosimbo NoNATo, que estão nos píncaros da cultura jurídica nacional, e cuja obra notável demonstra o esforço, a competência e o cuidado com que procuraram realizar o grande empreendimento que é a unificação do Direito Privado, em matéria de Obrigações. 